\title{
ТЕОРЕТИЧНИЙ АНАЛІЗ ПРОБЛЕМИ АМБІВАЛЕНТНОСТІ В ПСИХОЛОГІЧНИХ ДОСЛІДЖЕННЯХ
}

\author{
Наталія Кухарчук \\ аспірантка кафедри авіаційної психології \\ Національний авіаційний університет \\ 03058, Україна, м Київ, просп. Космонавта Комарова, 1 \\ nata.organicera@gmail.com, https://orcid.org/0000-0003-4992-0433
}

\begin{abstract}
Анотація
В статті висвітлені результати теоретичного дослідження психологічних поглядів на проблему амбівалентності. Амбівалентність розглядається у широкому розумінні, як тенденція уникнення вибору, що проявляється поведінково, когнітивно чи афективно, та спрямована на конкретну людину, подію, об’єкт чи, навіть, на майбутній досвід. Амбівалентність відіграє важливу роль у багатьох психоаналітичних теоріях, а також у соціологічних, когнітивних, розвивальних i психометричних підходах, у контексті нормального психологічного функціонування індивіда. Загальні філософські та психологічні точки зору свідчать про те, що амбівалентність може бути характерною ознакою для багатьох людей, та може формувати їхнє ставлення й взаємодію з оточуючим середовищем. Передумовами виникнення амбівалентності можуть бути: нестійкість емоцій, невизначеність цілей та установок, неузгодженість моральних принципів з емоціями та волею. Мета статті: висвітлення результатів теоретико-методологічного дослідження формування та розвитку психологічних поглядів на проблему амбівалентності в вітчизняній та закордонній науковій літературі. Методи дослідження: аналіз психологічної літератури, теоретичне узагальнення, порівняння вітчизняних та зарубіжних наукових підходів до визначення амбівалентності. Розглянуто складові амбівалентності: мотиваційна, поведінкова, афективно-когнітивна. Поданий теоретичний аналіз досліджень науковців: К. Абрагама, В. Блейхера, Е. Брейлера, М. Занни, Т. Зелінської, І. Козицької, М. Томпсона, З. Фрейда, К. Юнга та ін. Багатьма дослідниками доведено значний вплив амбівалентності на особистісне зростання й загальний стан психічного здоров'я людини. Узагальнено та обгрунтовано поняття амбівалентності як складного взаємозв'язку протилежно спрямованих, приблизно однакових за інтенсивністю, усвідомлених і неусвідомлених проявів, що належать до різних особистісних сфер.
\end{abstract}

Ключові слова: амбівалентність, компоненти амбівалентності, особистість, психологічний підхід.

\section{Вступ}

Важливими умовами всебічного розвитку людини є іï усвідомлене прагнення до повного розкриття та реалізації власних потенційних можливостей, усвідомлення свого життєвого шляху та досягнення поставлених цілей. У процесі динамічного розвитку сучасного суспільства особливого значення набуває здобутий людиною досвід у переживаннях і ситуаціях, які ставлять іiі перед необхідністю постійного вибору із взаємовиключних у часі альтернатив, коли, як наслідок, людина втрачає інший, можливий варіант вирішення ситуації. Усвідомлення особистістю можливості втрати однієї 3 
актуалізованих альтернатив, прийняття рішення, реалізації дії або вчинку призводить до того, що така ситуація набуває ознак антиномічності (Козицька, 2014).

Впродовж останніх років наша країна переживає становлення нової соціальної суб'єктивізації. Поглиблюється системна криза усіх сфер суспільного життя, яка ускладнюється перманентною психологічною кризою. Серед громадського загалу все більше переважає стан невизначеності, усвідомлення страху, незадоволення собою й оточенням, фрустрованість, соціальний песимізм та загальна амбівалентність почуттів (Врублевский \& Горпинюк, 2008). Одним із напрямків вирішення зазначених вище проблем є дослідження амбівалентності як динамічної властивості особистості, що стає варіативним регулятором усіх сфер життя, зумовлюючи специфіку їі розвитку.

Окреслене актуалізує вивчення психологічних поглядів на проблему амбівалентності.

Мета дослідження: теоретичний аналіз психологічних поглядів на проблему амбівалентності у вітчизняній і зарубіжній науковій літературі. Завдання дослідження: 1) проаналізувати основні зарубіжні наукові підходи до вивчення проблеми амбівалентності особистості; 2) проаналізувати основні вітчизняні наукові підходи до вивчення проблеми амбівалентності особистості.

\section{Методи дослідження}

Вивчення та аналіз психологічної літератури 3 теми дослідження; теоретичне узагальнення досвіду; порівняння вітчизняних та зарубіжних наукових досліджень проблеми амбівалентності.

\section{Результати та дискусії}

Термін «амбівалентність» (лат. ambo - обидва та valentia - сила) означає неузгодженість, суперечливість у ставленні до чогось (амбівалентність почуттів), подвійність чуттєвих переживань, яка виражається у тому, що один і той самий об'єкт викликає у людини одночасно два протилежних почуття, тобто неоднозначність у ставленні людини до оточуючого середовища.

Психологічні дослідження амбівалентності в зарубіжній психології можна умовно поділити на три напрями. Перший напрям - амбівалентність стає невід'ємним конструктом увага зосереджена на іiї психодинамічних аспектах (К. Абрахам, Д. Віннікотт, М. Клейн, 3. Фрейд). Напрям також розвивається у теоріях неофройдистів (А. Адлер, К. Юнг) та егопсихологів (Е. Еріксон, К. Хорні). Другий напрям презентований дослідженнями амбівалентності як виду психологічного конфлікту. Розкритий у теорії поля К. Левіна та когнітивної концепції Л. Фестінгера. До третього напряму належать гуманістичні теорії особистості К. Роджерса, А. Маслоу (Rodzhers, 2000; Maslou, 2007).

Амбівалентність у психології - це подвійне ставлення до предмета або людини, що суперечить одне одному, подвійне почуття або переживання. Об'єкт викликає дві абсолютно протилежні емоції. Вперше термін «амбівалентність» був відкритий швейцарським психіатром Е. Блейером на початку ХХ століття. На його думку, цей стан є першою ознакою шизофренії (Брейлер, 2001).

На противагу Е. Блейеру, 3. Фрейд вважав, що амбівалентність - це мирне співіснування у людській душі протилежних спонукань. Ці спонукання виникають у двох сферах (життя і смерть), та вважаються фундаментом особистості. Учений відзначив той факт, що людина народжується із подвійними емоціями. При цьому, позитивні - знаходяться 
на свідомому рівні, а негативні - заховані у глибинах підсвідомості. За сприятливих умов вони «спливають», провокуючи людину на непередбачувані та іноді неадекватні вчинки. Вивчаючи проблему «табу», 3. Фрейд досліджував його природу й виникнення неврозу. Вчений стверджував, що за наявною забороною приховується бажання. Тобто те, що категорично забороняється, повинно стати предметом пристрасті. Він вважав, що нав'язлива поведінка і амбівалентність мають спільне походження - взаємне стримування протилежних сил, які породжують фізичну напругу, а також потребу іï вивільнення. З. Фройд використовував термін «амбівалентність» як основне поняття структури особистості в своїй праці «Я $і$ Воно», висунувши теорію динамічної взаємодії трьох компонентів: Воно (id), Я (ego), Над-Я (super-ego). Первинна амбівалентність цієї структури полягає у несумісності між вимогами підструктур Воно та Над-Я (Фрейд, 1989).

Вчений К. Юнг розширив поняття про амбівалентність. За його позицією, свідоме й несвідоме гармонійно поєднались у механізмі дії людської психіки. Це існування у свідомості та підсвідомості двох протилежних або конфліктуючих почуттів, бажань, емоцій або намірів щодо одного й того ж явища, об’єкта, людини (Юнг, 1991).

Загальний аналіз психологічної літератури засвідчив, що термін «амбівалентність» має доволі важливе значення як у психоаналітичних теоріях особистості (М. Кляйн, Ш. Магомед-Емінов, Ф. Ріман, Дж. Стівенс, 3. Фрейд, А.Фрейд), так і в гуманістичній психології (К. Роджерс, Ф. Перлз, В. Франкл) (Перлз, 1993; Риман, 1998; Роджерс, 2000; Франкл, 1997, 1990; Фрейд А., 1999; Фрейд 3., 1998).

Погляди 3. Фрейда про амбівалентність продовжували відігравати основне роль у психоаналітичних теоріях розвитку (К. Абрагам, Д. Віннікотт, М. Клейн, А. Фрейд) К. Абрагам пов'язує наявність амбівалентності зі стадіями розвитку лібідо, акцентуючи іiі значну роль у своїй теорії. Він підкреслював, що індивід, який неспроможний досягти цілісного розвитку лібідо, повертається на ранню стадію. Амбівалентність на оральній стадії в ситуації зриву, на шляху іiї прогресивного розвитку, призводить до маніакальних (злиття 3 матір'ю) і депресивних (втрата матері) коливань настрою. Фіксація на анальній стадії розвитку виявляється в агресивних намірах, садизмі чи мазохізмі, бісексуальності. Регресія особистості до фалічної амбівалентності виникає як неподоланий у дитинстві страх кастрації, що виявляється у неприйнятті залежного становища, прагненні домінування, агресивності або холодній стриманості та глибокій депресії (Абрахам, 2014).

В теорії психічного розвитку М. Кляйн, як i у попереднього автора, поняття амбівалентності відіграє суттєву роль. Різниця полягає у тому, що авторка відмовляється від понять стадій розвитку й точок фіксації на користь теорії позицій та надає більшого значення саме першому року життя, ніж дитинству загалом (Кляйн, 2011).

Неофройдисти А. Адлер і К. Юнг продовжили вивчення проблеми амбівалентності. Фундатор індивідуальної психології А. Адлер, відмовившись від психоаналітичної теорії амбівалентності, розглядав цей феномен як нестабільне ставлення, що спрямоване на уникнення розв'язання важливої проблеми. Він вважав основним постулатом своєї теорії уявлення про людину як про єдину самоузгоджену цілісність (Юнг, 1991).

Е. Еріксон (Эриксон, 1996) у своїх працях виокремив вісім стадій психосоціального розвитку «Его» та визначив специфіку кожної фази в соціальному розвитку. Кожна стадія супроводжується кризою, яка складається із позитивного та негативного аспектів. На кожній стадії розвитку «Его» набуває одну амбівалентну якість (базова довіра - базова недовіра, Его-ідентичність - рольове заміщення, інтимність - ізоляція та ін.) (Зелінська, 2004). 
В соціокультурній теорії особистості К. Хорні розширила зміст амбівалентності, дослідивши поняття нормального внутрішнього і невротичного внутрішнього конфлікту. Джерелом розвитку будь-якого внутрішнього конфлікту $\epsilon$ незадоволення невротичних потреб, що формується із необхідності подолати базальну тривогу, яка виникає у дитинстві, внаслідок відсутності відчуття безпеки у міжособистісних стосунках (Хорни, 2016).

В іншому напрямі амбівалентність вивчали К. Левін і Л. Фестінгер. Ідея дослідження полягає у тому, що конфлікт трапляється у психологічних ситуаціях, де протилежно спрямовані й приблизно рівні сили одночасно впливають на особистість (Левин, 2000).

Психологи Г. Нюнберг та Е. Фромм у своїх дослідженнях довели прямий зв'язок між проблемами суспільства і психологічними станами індивіда. А саме: зростання драматичних колізій зовнішнього світу збільшує рівень особистої амбівалентності індивіда. На думку Г. Нюнберга, остання завжди відображає тенденцію відштовхувати або приймати зовнішній світ, хоча важливе значення має рівень перебігу цього процесу (Нюнберг, 1999).

Згідно А. Маслоу, сили, що впливають на індивіда, мають не один, а два напрями. Амбівалентність заважає духовному зростанню та самоактуалізації: крім того, що є сили, які підштовхують людину в бік здоров'я, існує регресивний вплив, що спрямовує індивіда в протилежний бік - до хвороб та слабкості (Maslou, 2007; Зелінська, 2004).

Проблемами амбівалентності займалися й такі психологи, як: Л. Анциферова, Л. Божович, Л. Виготський та ін. Зокрема, Л. Божович (Божович, 1995) проаналізувала феномен «смислового бар'єру» та «ефекту неадекватності» в школярів, що є наслідком одночасної актуалізації двох протилежних мотиваційних тенденцій. Ці поняття використовуються у контексті вивчення внутрішніх суперечностей та становлять інтерес $\mathrm{i}$ для дослідження передумов виникнення амбівалентності.

Сучасні науковці та практики в сфері психології часто звертаються до феномена антиномічності, розкриваючи його в своїх наукових i психотерапевтичних працях. Психотерапевт І. Ялом, досліджуючи процес психотерапії, підкреслив, що рішення буває важко прийняти із багатьох причин, окремі з них є в основі нашого буття (Ялом, 2000).

Проблему амбівалентності в психологічному аспекті також вивчала I. Міхєєва (Михеева, 1991). Однак авторка не зуміла відшукати амбівалентність у внутрішньому світі гармонійної особистості та не розкрила перебіг ії деформаційних змін від психічно здорової до душевно хворої людини. Без вирішення цих питань неможливе фундаментальне вивчення проблеми амбівалентності особистості. Так, лише кілька вітчизняних досліджень присвячені певним аспектам особистісної амбівалентності, саме як морально психологічної проблеми та амбівалентності в поведінці дітей раннього віку щодо незнайомого дорослого, а також розвитку в дітей уявлень про амбівалентні емоції (Зелінська, 2004).

Сучасні психологи України також активно вивчали феномен амбівалентності особистості. У своєму дисертаційному дослідженні Т. Лук'яненко описала психологічні особливості особистісної амбівалентності в ранньому юнацькому віці, залежно від вияву структурних компонентів за віком і статтю (Лук'яненко, 2001). Отримані результати ілюструють значно менше виражений, але розбалансований низький узгоджений рівень особистісної амбівалентності в юнаків старших класів, ніж у дівчат. Встановлені особливості міжособистісних стосунків учнів раннього юнацького віку: в хлопців - більша прямолінійність, відвертість проявів агресивності, у дівчат - непряме, більш опосередковане, приховане спрямування агресії. Т. Зелінська визначила амбівалентність як властивість психічно здорової особистості із помірною напругою суперечностей, а також дослідила 
деструктивні прояви амбівалентності високого ступеню (інфантильні залежності в різних сферах життя) (Зелінська, 2004). В. Хабайлюк вивчала суперечності в підсистемах сімейних стосунків «дитина - мати», «дитина - батько», «дитина - брати та сестри», «дитина прабатьки», «дитина - інші люди» (Хабайлюк, 2014).

Дослідниця А. Хурчак розглянула амбівалентність атитюдів у контексті західних підходів до вивчення цього феномена (Хурчак, 2004). Західні вчені розробили опитувальник «Вимірювання амбівалентності атитюдів», у якому використовується індекс подібностіінтенсивності (Thompson \& Zanna, 1995).

В зазначених визначеннях феномена амбівалентності підкреслено ставлення суб'єкта до об’єкта, до самого себе або суперечливі стани емоційної та поведінкової сфер.

Різнобічна характеристика феномена, який досліджується, уможливив виокремлення таких компонентів амбівалентності:

$\checkmark$ одночасна подвійність явищ зовнішньої реальності або внутрішнього світу;

$\checkmark$ взаємонепримирення протилежності мотиваційної, афективної, поведінкової сфер особистості; характеризуються рівною чи майже рівною силою й обсягом: рівновага i сталість явища, які пов'язані із однаково наявним протиставленням тенденцій, полярних за своєю суттю;

$\checkmark$ співіснування протилежностей у формі амбітендентності, тобто єдності свідомого та несвідомого, чим, власне, й відрізняються від внутрішньоособистісного конфлікту;

$\checkmark$ амбітендентність має помірний вияв, здатна до інтеграції, тому становлення особистості відбувається в конструктивному ритмоциклі;

$\checkmark$ надмірна амбітендентність майже не інтегрується, через що розвиток особистості відбувається із переважанням деструктивних чи навіть патологічних умов (Борисюк \& Прохорчук, 2017).

Оскільки вище відзначено, що амбівалентність $є$ властивістю особистості, то можна виокремити такі її складові: мотивачійну, поведінкову, афективно-когнітивну.

Мотиваційна складова амбівалентності особистості полягає в так званій двомодальності, позитивно-негативній iї побудові, відповідно до потреб у афіліації, яка реалізується як прагнення до прийняття, з одного боку, і як страх знехтування - 3 іншого. К. Мюррей, Ю. Орлов, К. Хорні, Б. Сосновський вважали, що зазначена потреба $\epsilon$ високопрезентативною і, власне, людською. Індивід не може одночасно реалізовувати два абсолютно різні спонукання, здійснювати дії, що заперечують одна одній, без спеціальної керівної системи, яка й становить пріоритети активності.

Поведінкова складова особистісної амбівалентності виявляється в площині внутрішньої боротьби між доброзичливістю та агресивністю. Як вважає П. Блос, поведінкова амбівалентність, що $є$ складовою дорослішання, коливається між двома крайнощами: активність і пасивність; ініціативність та поступливість. Такі процеси вчений пов'язував із регресивною поведінкою особистості, що визначається як норма при переході із дитинства в дорослість. Але в дорослої, зрілої особистості $є$ аномальною (Блос, 2010). Доброзичлива поведінка є свідченням узгодженості амбівалентності. Доброзичливість є основною якістю індивіда, не лише фактором стримання агресії, а й iї альтернативою (Реан, 2007).

Афективно-когнітивну складову амбівалентності особистості презентує одночасна двомодальність, поляризація цих двох сфер у протилежних напрямках. Переживання задоволення-незадоволення передбачає одночасне усвідомлення особистістю толерантностіінтолерантності до цієї подвійності, або фрустраційної толерантності. М. Занна і М. Томпсон 
вважали, що афективно-когнітивний компонент $\epsilon$ найбільш стійким в особистісній амбівалентності, тобто, коли розум говорить одне, а серце інше (Thompson \& Zanna, 1995).

Отож, амбівалентність розглядається у широкому розумінні як тенденція уникнення вибору, що проявляється поведінково, когнітивно чи афективно та спрямована на конкретну людину, подію, об’єкт чи, навіть, на майбутній досвід.

\section{Висновки}

За результатами проведеного теоретичного аналізу проблеми амбівалентності в психологічній літературі встановлено, що амбівалентність - це складний взаємозв'язок протилежно спрямованих i приблизно однакових за інтенсивністю усвідомлених й неусвідомлених проявів, що належать до різних особистісних сфер буття людини. Вони можуть перебувати в узгодженому або неузгодженому стані. Багато вчених довели значний вплив амбівалентності на особистісне зростання та на загальний стан психічного здоров'я людини. Передумовами виникнення амбівалентності є: нестійкість емоцій, невизначеність цілей і установок, неузгодженість моральних принципів з емоціями і волею. Зарубіжні вчені досліджували амбівалентність в руслі психоаналітичного, когнітивного і гуманістичного напрямів. Узагальнюючи психологічні підходи вчених до вивчення амбівалентності, зазначимо, що вони пов'язували цей феномен зі стадіями розвитку лібідо, 3 процесами розщеплення та інтеграції індивідом об'єктів оточуючого середовища та з певними формами страхів. Джерелом усіх прагнень особистості до саморозвитку є почуття неповноцінності. Прояв амбівалентності особистості: будь-які їі вчинки спрямовані на подолання почуття неповноцінності й зміцнення почуття значущості в соціумі.

Перспективи подальшого дослідження полягають в емпіричному вивченні амбівалентності особистості на різних вікових етапах.

\section{Література}

1. Абрахам, К. (2014). Психоанализ как источник познания для наук о духе. Ижевск : Слово.

2. Брейлер, Э. (2010). Аффективность внушение, паранойя. Москва : Центр психологии культуры.

3. Блос, П. (2010). Психоанализ подросткового возраста. Москва : Институт общегуманитарных исследований.

4. Божович, Л. (1995). Избранные психологические труды. Проблемы формирования личности. Москва : Международная педагогическая академия.

5. Борисюк, О.М., \& Прохорчук, Н.В. (2017). Амбівалентність особистості як психологічний феномен. Науковий вісник Львівського державного університету внутрішніх справ, 2, 80-91. Режим доступу: https://olhaborysiuk.lviv.ua/nauk-pr/

6. Врублевский, В., \& Хорошковский, В. (1997). Український шлях. Київ : Демократична Україна.

7. Горпинюк, В.П. (2008). Амбівалентність як чинник соціальних девіацій у сімейних взаєминах. Теоретико-методичні проблеми виховання дітей та учнівської молоді, 5, 475481. Режим доступу: http://lib.iitta.gov.ua/3018/

8. Эриксон, Э. (1996). Молодой Лютер. Психоаналитическое историческое исследование. Москва : Московский философский фонд «Медиум».

9. Зелінська, Т. (2004). Амбівалентність особистості. Київ : Каравела.

10. Кляйн, М. (2011). Развитие в психоанализе. Москва : Академичский проект.

11. Левин, К. (2000). Теория поля в социальных науках. Санкт-Петербург : Речь. 
12. Лук'яненко, Т.Н. (2001). Психологічні особливості дискордантної амбівалентності особистості. Практична психологія та соиіальна робота, 1, 25-26. Режим доступу: http://enpuir.npu.edu.ua/bitstream/123456789/6035/1/Lukyanenko.pdf

13. Нюнберг, Г. (1999). Приниипь психоанализа и их применение к лечению неврозов: Московский ин-т общегуманитарных исследований. Москва : ЭКСМО-Пресс.

14. Перлз, Ф., Хеффермен, Р., \& Гудмэн, П. (1993). Опыты психологии самопознания. Москва : Гильстель.

15. Реан, А. (2007). Общзая психология и психология личности. Москва : ЭКСМО-Пресс.

16. Риман, Ф. (1998). Основные формы страха. Москва : Алетейа.

17. Роджерс, К. (2000). Консультирование и психотерапия. Новейшие подходы в области практической работы. Москва : ЭКСМО-Пресс.

18. Франкл, В. (1990). Человек в поисках смысла. Москва : Прогресс.

19. Франкл, В. (1997). Доктор и душа. Санкт-Петербург : Ювента.

20. Фрейд, А. (1999). Теория и практика детского психоанализа. Москва : ЭКСМО-Пресс.

21. Фрейд, 3. (1989). Психология бессознательного: сборник произведений. Москва : Просвещение.

22. Хабайлюк, В.В. (2014). Життєва та професійна компетентність студентів. Обрій, 2, 80-83. Режим доступу: http://nbuv.gov.ua/UJRN/obrii_2014_2_24

23. Хорни, К. (2016). Невротическая личность нашего времени. Nykoping : Philosophical arkiv.

24. Хурчак, А.Е. (2004). Психологічні особливості амбівалентності атитюдів у юнацькому віuі. (Дис. канд. психол. наук). Київ.

25. Юнг, К. (1991). Архетип и символ. Москва : Реннесанс.

26. Ялом, И. (2000). Экзистенциальная психотерапия. Москва : Класс.

27. Maslou, A. (2007). Motivation and Personality (3rd ed.). Saint Petersburg : Piter.

28. Rodzhers, K. (2000). Counseling and psychotherapy. The newest approaches in the field of practical work. Москва : EKSMO.

29. Thompson, M., \& Zanna, M. (1995). The conflicted individual: personality-based and domainspecific antecedents of ambivalent social attitudes. Journal of personality, 63(2), 259-288. Режим доступу: https://pubmed.ncbi.nlm.nih.gov/7782994/

\section{References}

1. Abraham, K. (2014). Psikhoanaliz kak istochnik poznaniya dlya nauk o dukhe [Psychoanalysis as a source of knowledge for the sciences of the spirit]. Izhevsk : Slovo [in Russian].

2. Blejhker, E. (2001). Affektivnost' vnusheniye, paranoyya [Affectivity suggestion, paranoia]. Moscow : Center psyhologii culture [in Russian].

3. Blos, P. (2010). Psikhoanaliz podrostkovogo vozrasta [Psychoanalysis of adolescence]. Moscow : Institut obshegumanitarnux isledovanij [in Russian].

4. Boshovich, L. (1995). Izbrannyye psikhologicheskiye trudy. Problemy formirovaniya lichnosti [Selected psychological works. Personality formation problems]. Moscow: Megdunarodnaya pedagogicheskaya akademia [in Russian].

5. Borisuk, O.M., \& Prokhorchuk, N.V. (2017). Ambivalentnist osobystosti yak psykholohichnyy fenomen [Personality ambivalence as a psychological phenomenon]. Naykovuj vicnuk Lvivskogo dershavnogo universitetu vnutrishnix sprav - Scientific Bulletin of Lviv State University of Internal Affairs, 2, 80-91. Retrieved from https://olhaborysiuk.lviv.ua/nauk-pr/ [in Ukraine].

6. Vrublevskij, V., \& Khoroshkovskij, V. (1997). Ykrainskij shlach [Ukrainian way]. Kyiv : Democratuchna Ykrajna [in Ukraine].

7. Gorpinuk, V.P. (2008). Ambivalentnist yak chynnyk sotsial nykh deviatsiy u simeynykh vzayemynakh [Ambivalence as a factor of social deviations in family relationships]. Teoretukometoduchni problemu vukhovannya ditey ta ychnivskoj molodi - Theoretical and methodological problems of education of children and students, 5, 475-481. Retrieved from http://lib.iitta.gov.ua/3018/ [in Ukraine]. 
8. Erickson, E. (1996). Molodoy Lyuter. Psikhoanaliticheskoye istoricheskoye issledovaniye [Young Luther. Psychoanalytic historical research]. Moscow : Moscow philosophical foundation "Medium" [in Russian].

9. Zelinska, T. (2004). Ambivalentnost osobustosti [Personality ambivalence]. Kyiv : Karavela [in Ukraine].

10. Klajn, M. (2011). Razvitie v psyhoanalize [Development in psychoanalysis]. Moscow : Akademicheskij project [in Russian].

11. Levin, K. (2000). Teoriya polya v sotsial'nykh naukakh [Field theory in the social sciences]. Saint Petersburg : Resh [in Russian].

12. Luk'yanenko, T.N. (2001). Psykholohichni osoblyvosti dyskordantnoyi ambivalentnosti osobystosti [Psychological specialties of discordant ambivalences]. Praktychna psykholohiya ta sotsialna robota - Practical psychology and social work, 1, 25-26. Retrieved from http://enpuir.npu.edu.ua/bitstream/123456789/6035/1/Lukyanenko.pdf [in Ukraine].

13. Nyunberg, G. (1999). Printsipy psikhoanaliza $i$ ikh primeneniye $k$ lecheniyu nevrozov: Moskovskiy in-t obshchegumanitarnykh issledovaniy [Principles of psychoanalysis and their application to the treatment of neuroses: Moscow Institute of General Humanitarian Research]. Moscow : EKSMO-Press [in Russian].

14. Perls, F., Hefferman, R., \& Goodman, P. (1993). Opyty psikhologii samopoznaniya [Experiments in the psychology of self-knowledge]. Moscow : Gilstel [in Russian].

15. Rean, A. (2007). Obshchaya psikhologiya i psikhologiya lichnosti [General psychology and psychology of personality]. Moscow : EKSMO-Press [in Russian].

16. Riemann, F. (1998). Osnovnyye formy strakha [Basic forms of fear]. Moscow : Aleteya [in Russian].

17. Rogers, K. (2000). Konsul'tirovaniye $i$ psikhoterapiya. Noveyshiye podkhody $v$ oblasti prakticheskoy raboty [Counseling and psychotherapy. The latest approaches in the field of practical work]. Moscow : EKSMO-Press [in Russian].

18. Frankl, V. (1990). Chelovek v poiskakh smysla [Man in search of meaning]. Moscow : Progress [in Russian].

19. Frankl, V. (1997). Doktor i dusha [Doctor and soul]. Saint Petersburg : Juventa [in Russian].

20. Freud, A. (1999). Teoriya i praktika detskogo psikhoanaliza [Theory and practice of child psychoanalysis]. Moscow : EKSMO-Press [in Russian].

21. Freud, Z. (1989). Psikhologiya bessoznatel'nogo: sbornik proizvedeniy [Psychology of the unconscious: a collection of works]. Moscow : Prosveshcheniye [in Russian].

22. Khabailyuk, V.V. (2014). Zhyttyeva ta profesiyna kompetentnist studentiv [Life and professional competence of students]. Obriy - Horizon, 2, 80-83. Retrieved from http://nbuv.gov.ua/UJRN/obrii_2014_2_24 [in Ukraine].

23. Horney, K. (2016). Nevroticheskaya lichnost' nashego vremeni [The neurotic personality of our time]. Nykoping : Philosophical arkiv [in Russian].

24. Khurchak, A.Ye. (2004). Psykholohichni osoblyvosti ambivalentnosti atytyudiv u yunatskomu vitsi [Psychological peculiarities of ambivalence attitudes in a young person]. Candidate's thesis. Kyiv [in Ukraine].

25. Jung, K. (1991). Arkhetip i simvol [Archetype and symbol]. Moscow : Renaissance [in Russian].

26. Yalom, I. (2000). Ekzistentsial'naya psikhoterapiya [Existential psychotherapy]. Moscow : Class [in Russian].

27. Maslou, A. (2007). Motivation and Personality (3rd ed.). Saint Petersburg: Piter.

28. Rodzhers, K. (2000). Counseling and psychotherapy. The newest approaches in the field of practical work. Moscow : EKSMO-Press.

29. Thompson, M., \& Zanna, M. (1995). The conflicted individual: personality-based and domainspecific antecedents of ambivalent social attitudes. Journal of personality, 63(2), 259-288. Retrieved from https://pubmed.ncbi.nlm.nih.gov/7782994/ 


\title{
THEORETICAL ANALYSIS OF AMBIVALENCE PROBLEMS IN PSYCHOLOGICAL RESEARCH \\ Natalia Kukharchuk \\ Postgraduate student of the Department Aviation Psychology \\ National Aviation University \\ 1, Cosmonaut Komarov Avenue, Kyiv, Ukraine, 03058 \\ nata.organicera@gmail.com, https://orcid.org/0000-0003-4992-0433
}

\begin{abstract}
The article highlights the results of a theoretical study in the formation and development of philosophical and psychological views on the problem of ambivalence. Ambivalence is studied in a broad sense as a tendency to avoid a choice that manifests itself behaviorally, cognitively, and is aimed at a specific person, event, object, or even future experience. Ambivalence plays an important role in many psychoanalytic theories, as well as sociological, cognitive, developmental and psychometric approaches, in the context of the normal psychological functioning of the individual. General philosophical and psychological points of view suggest that ambivalence can be a characteristic feature of many people, and can shape their attitudes and interactions with the environment. Prerequisites for the emergence of ambivalence can be: instability of emotions, uncertainty of goals and attitudes, inconsistency of moral principles with emotions and willpower. Research on the aim of the article was to highlight the results of theoretical and methodological research on the formation and development of philosophical and psychological views of the problem of ambivalence in domestic and foreign scientific literature. Research methods: analysis of psychological literature, theoretical generalization, comparison of domestic and foreign scientific approaches to determining ambivalence. The following components of ambivalence are considered: motivational, behavioral and affective-cognitive ones. The theoretical research analysis of outstanding scientists of the past and present is presented: K. Abraham, W. Bleicher, E. Breiler, M. Zanna, T. Zelinska, I. Kozytska, M. Thompson, Z. Freud, K. Jung and others. Many studies have shown a significant effect of ambivalence on personal growth and overall mental health. The conclusions summarize and substantiate the concept of ambivalence as a complex relationship of oppositely directed, approximately equal in intensity, conscious and unconscious manifestations belonging to different personal spheres.

Keywords: ambivalence, components of ambivalence, personality, psychological approach.
\end{abstract}

Подано 15.12.2020

Рекомендовано до друку 07.06.2021 